\title{
Peran Model Pembelajaran Giving Question and Getting Answers Berbantuan Media Powerpoint terhadap Kompetensi Pengetahuan PPKn
}

\author{
Ni Made Widiantari \\ Program Studi Pendidikan Guru Sekolah Dasar, Universitas Pendidikan Ganesha \\ made.widiantari@undiksha.ac.id
}

I G A Agung Sri Asri

Program Studi Teknologi Pendidikan, Universitas Pendidikan Ganesha (9 Pt) igaagungsri.asri@undiksha.ac.id

I Gusti Agung Oka Negara

Program Studi Pendidikan Guru Sekolah Dasar, Universitas Pendidikan Ganesha igustiagungoka.negara@undiksha.ac.id

\begin{tabular}{l} 
A R T I C L E I N F O \\
\hline Article history: \\
1 Juli 2020 Received in \\
revised form \\
30 Agustus 2020 \\
Accepted 28 September 2020 \\
Available online \\
30 September 2020 \\
\\
\hline Kata Kunci: \\
GQGA, powerpoint, \\
kompetensi pengetahuan \\
PPKn \\
Keywords: \\
GQGA, powerpoint, \\
knowledge competency of \\
PPKn
\end{tabular}

\begin{abstract}
ABSTRAK
Penelitian ini bertujuan untuk menganalisi pengaruh yang signifikan model pembelajaran Giving Question And Getting Answers berbantuan media powerpoint terhadap kompetensi pengetahuan PPKn siswa kelas IV SD. Penelitian ini adalah penelitian eksperimen semu, menggunakan nonequivalent control group design. Populasi penelitian terdiri dari 9 kelas SD kelas IV dengan sampel 36 siswa sebagai kelompok eksperimen, dan 32 siswa sebagai kelompok kontrol. Data dari kompetensi pengetahuan PPKn dikumpulkan dengan tes objektif. Hasil rata-rata gain skor pretest dan posttest kompetensi pengetahuan PPKn menunjukkan kelompok eksperimen memperoleh hasil 0,655 lebih tinggi dari rata-rata kompetensi pengetahuan PPKn kelas kontrol yaitu 0,538. Data kompetensi pengetahuan PPKn dianalisis memakai
\end{abstract} uji-t polled varians. Hasil analisis dengan uji-t menunjukkan $\mathrm{t}_{\text {hitung }}=2,053>\mathrm{t}_{\mathrm{tabel}}=1,997$. Jadi, terdapat perbedaan yang signifikan kompetensi pengetahuan PPKn kelompok siswa yang dibelajarkan menggunakan model pembelajaran Giving Question and Getting Answers berbantuan media powerpoint dengan kelompok siswa yang dibelajarkan menggunakan pembelajaran konvensional pada kelas IV SD. Dengan demikian, model pembelajaran Giving Question And Getting Answers berbantuan media powerpoint berpengaruh terhadap kompetensi pengetahuan PPKn siswa kelas IV SD. 
significant difference in terms of knowledge competence of PPKn between groups of students who were taught using the Giving Question and Getting Answers learning model assisted by powerpoint media and the group of students who were taught using conventional learning among students grade IV SD. In conclusion, the learning model of Giving Question and Getting Answers assisted by powerpoint media had an effect on the knowledge competence of PPKn among students grade IV SD.

\section{PENDAHULUAN}

Sarana utama untuk melengkapi setiap kebutuhan manusia didapat melalui pendidikan, baik dengan pendidikan informal maupun pendidikan formal. Pendidikan biasanya dilihat melalui sebuah kebutuhan yang sama dengan kebutuhan lainya bagi suatu bangsa yang berkeinginan untuk maju. Dalam hal ini dipastikan dalam peningkatan setiap mutu pendidikan berpengaruh akan perkembangan suatu bangsa. Sehingga, dalam perkembangan suatu bangsa perlu melahirkan sumber daya manusia yang memiliki kualitas melalui pendidikan baik serta bermutu. Melalui pendidikan dapat memberikan seseorang tersebut kemampuan ilmu pengetahuan, kemampuan perilaku, serta kemampuan keterampilan yang didapat dalam pendidikan kelak tentu sangat berguna untuk masa depan, bermanfaat untuk masyarakat, bangsa serta negara. Sehingga, pendidikan ialah suatu proses yang berkelanjutan dan tak pernah berakhir yang diiringi melalui usaha sadar yang terancang yang dapat menghasilkan kualitas yang berkesinambungan yang ditujukan pada perwujudan sosok manusia masa depan dan berakar pada nilai-nilai budaya bangsa serta Pancasila (Sujana, 2019). Tujuan pendidikan adalah untuk mengembangakan potensi yang dimiliki oleh siswa untuk menjadikan seorang manusia memiliki iman serta bertaqwa pada Tuhan Yang Maha Esa, tekun dalam menuntut ilmu, baik dalam bercakap, memiliki kreativitas yang tinggi, dan tidak bergantung pada orang lain mampu jadi warga negara Indonesia yang baik menurut Pancasila serta memiliki rasa bertanggung jawab atas semua perbuatannya. Pada dasarnya pemerintah Indonesia sudah melakukan perubahan kurikulum, dari Kurikulum 2006 yang dikenal menjadi Kurikulum Tingkat Satuan Pendidikan serta saat ini sebagai Kurikulum 2013 hanya berfokus pada siswa. Pada kurikulum 2013, pembelajarannya memakai pendekatan saintifik dengan pembelajaran tematik integratif (Setiadi, 2016). Dalam hal ini, muatan pelajaran yang diintegrasikan pada kurikulum 2013 hendak mengharuskan siswa untuk membangun pengetahuannya sendiri serta muatan materi yang digunakan sebagai wahana dalam mengembangkan dan melestarikan nilai luhur dan moral yang berakar pada budaya bangsa Indonesia yaitu dalam muatan materi pembelajaran PPKn.

Muatan pembelajaran PPKn ialah mata pelajaran yang wajib di sekolah dasar. Siswa sekolah dasar harus ditanamkan jiwa nasional sejak dini sehingga kedepan siswa memahami makna dari tujuan dan cita-cita Negara Indonesia dengan cara mengenali ataupun mengetahui identitas dari negaranya sendiri (Harahap, 2018). Pada dasarnya pembelajaran PPKn di sekolah dasar memberikan pelajaran pada siswa untuk memahami dan membiasakan siswa dalam kehidupan di sekolah maupun di luar sekolah, karena materi PPKn menekankan pada pengalaman dan pembiasaan dalam kehidupan sehari-hari yang ditunjang oleh pengetahuan dan pengertian sederhana sebagai bekal untuk mengikuti pendidikan selanjutnya (Selly Lindayani et al., 2019). PPKn apabila dilihat lebih luas bukan hanya program pengajaran yang hanya meningkatkan pengetahuan kewarganegaraan, akan tetapi mengembangkan nilai ataupun karakter yang disertakan dengan keterampilanketerampilan lainnya sehingga siswa mampu berpartisipasi secara efektif (Aprilia et al., 2018). Misi dari mata pelajaran PPKn adalah mengembangkan keadaban Pancasila yang mampu membudayakan dan memberdayakan siswa menjadi warganegara yang cedas dan baik serta menjadi seorang pemimpin bangsa dan negara Indonesia di masa depan yang amanah, jujur, cerdas, dan bertanggungjawab (Nurhafni \& Khasanah, 2019). Melalui PPKn diharapkan siswa mampu menyerahkan suatu perhatiannya bagi pengembangan nilai, memiliki moral yang baik, serta sikap dalam perilaku yang sesuai dengan Pancasila. 
Sejatinya, PPKn ialah mata pelajaran berhubungan dengan kehidupan yang terjadi di sehari-hari, yang memberikan pelajaran secara menyeluruh upaya dalam pembentukan karakter individu untuk jadi warga negara cerdas, baik serta dapat menjunjung tinggi nilainilai yang ada di Pancasila yakni dasar negara Indonesia serta mampu membopong negara Indonesia menuju dalam suatu perubahan yang lebih baik (Tukiran, 2019). Sehingga dirangkum bahwa pelajaran PPKn yaitu untuk menumbuh kembangkan wawasan serta kesadaran siswa dalam berbangsa serta bernegara Indonesia, mempunyai perilaku rasa cinta akan tanah air yang beralaskan budaya beserta filsafat bangsa Pancasila, wawasan dalam nusantara serta ketahanan dalam nasional pada siswa sebagai calon anggota penerus bangsa ini yang hendak membopong bangsa Indonesia menuju kearah perubahan yang lebih baik. Pada kenyataannya pembelajaran PPKn dianggap ilmu yang mudah tetapi pada dasarnya kadang-kadang merupakan hal yang tidak masuk akal dan membinggungkan bagi siswa, Hal umum seperti ini yang sering dijumpai oleh guru pada saat mengajar materi PPkn di kelas (Ifnasari, 2018).

Berdasarkan informasi yang diperoleh dari hasil observasi kepada guru kelas IV yang ada di SD Gugus III Mengwi Tahun Ajaran 2019/2020 pada pelaksanaan pembelajaran tematik, lebih tepatnya pada pengintegrasian mata pelajaran yang memuat PPKn belum bisa terlaksana dengan optimal. Permasalah yang terjadi adalah masih kurangnya dalam mengkonstruksi setiap pengetahuan awalnya yang dimiliki oleh siswa melalui gagasan baru dipelajarinya yang dapat mengakibatkan : 1) siswa menjadi kurang dalam memiliki rasa untuk ingin tahu yang amat mendalam mengenai materi pelajaran yang telah diberikan, 2) siswa menjadi kurang dalam berpartisipasi untuk mengajukan sebuah pertanyaan, 3) siswa kurang bisa menjawab apabila guru memberikan sebuah pertanyaan, 4) siswa kurang dalam kemampuan mengkomunikasikan pada proses pembelajaran yang berlangsung sehingga berpengaruh dalam pencapaian kompetensi pengetahuan PPKn yang dimiliki siswa belum optimal, 5) kegiatan pembelajaran yang kurang menarik dan masih menoton karena dalam memakai model pembelajaran dan media pembelajaran yang kurang bervariasi hanya berorientasi pada siswa. Hal ini menyebabkan suasana pembelajaran menjadi kurang bermakna bagi siswa. Dengan demikian, dalam konsep yang diperoleh belum mampu diaplikasikan pada kehidupan siswa sehari-hari dengan benar. Maka, disinilah seorang guru mengupayakan untuk perlu penerapan model suatu pembelajaran yang inovatif di dalam setiap kegiatan proses pembelajaran sehingga mampu meningkatkan kompetensi pengetahuan PPKn siswa.

Mengacu pada pemaparan diatas, maka penelitian ini dilakukan sebagai solusi dalam memecahkan permasalahan tersebut. Salah satunya adalah menerapkan model pembelajaran Giving Question and Getting Answers berbantuan media powerpoint pada pembelajaran bermuatan PPKn sehingga dapat membangkitkan situasi belajar lebih menyenangkan, aktif, serta bermakna untuk siswa, serta mengajak siswa untuk lebih membuka wawasan pada setiap materi pembelajaran yang pelajari. Melalui pembelajaran tersebut bisa digunakan sebagai alternatif pilihan, yang berarti guru bisa memutuskan setiap model dan media yang pas serta efisien sebagai satu upaya guna pencapaian tujuan dari pembelajaran.

Model pembelajaran Giving Question and Getting Answers ialah pelaksanaannya melalui suatu pembelajaran konstruktivistik yang mengikutsertakan siswa selaku subjek di dalam berlangsungnya pembelajaran. Model pembelajaran ini merupakan pembelajaran aktif untuk meningkatkan kemampuan berfikir siswa dalam berbagai pengetahuannya dengan membentuk kelompok belajar. Model ini juga didesain untuk menghidupkan kelas dengan suasana belajar yang menyenangkan serta melibatkan gerak fisik siswa (Sudirman, 2015). Hal ini sesuai dengan hasil penelitian (Nengsi \& Oktaria, 2019) giving question and getting answers merupakan salah satu dari tipe model pembelajaran kooperatif yang merangsang siswa untuk atif di dalam kelas serta mendengarkan semua penjelasan guru. Hasil penelitian (Riza \& Sthephani, 2020) model giving question and getting answers adalah pembelajaran yang diarahkan untuk membangun tim dan melibatkan siswa dalam 
meninjau ulang materi pelajaran yang dapat memberikan kesempatan pada siswa utnuk bertanya mengenai hal yang tidak dimengerti dan memberikan kesempatan pada siswa untuk menjelaskan hal yang sudah dimengerti kepada temannya yang lain. Sependapat juga dengan hasil penelitian (Sastra et al., 2020) giving question and getting answers siswa didorong untuk mengajukan sebuah pertanyaan yang produktif, dengan ini akan mendorong siswa untuk mandiri dan mengembangkan keterampilan ilmiah dan implementasinya. Siswa dapat menemukan ilmu yang terdapat dalam materi pembelajaran dengan cara mencari sendiri dan seorang guru hanya menjadi motivasi dan fasilitator saja (Asmini, 2020). Model pembelajaran ini dapat membuka wawasan siswa terhadap materi yang telah siswa pelajari. Sehingga siswa tidak hanya menerima semua pelajaran dari apa yang disampaikan guru dan tentunya siswa lebih termotivasi dalam belajar, mudah dalam mengingat dan memahami suatu materi pelajaran (Ayuningsih \& Ciptahadi, 2020). Pada model ini diterapkan guna membiasakan siswa mempunyai kemampuan serta keterampilan dalam bertanya serta menjawab sebuah pertanyaan, dikarenakan dari dasarnya model ini yakni modifikasi yang berawal metode tanya jawab serta metode ceramah berdasarkan dari kolaborasi melalui penggunaan potongan-potongan kertas semacam sarana (Fitriani et al., 2016). Tujuan model Giving Question And Getting Answers yaitu mengecek pemahaman para siswa sebagai dasar perbaikan proses belajar mengajar, membimbing para siswa untuk memperoleh suatu keterampilan kognitif maupun sosial serta memberikan rasa senang pada siswa. Memotivasi siswa agar terlibat dalam interaksi, melatih kemampuan mengutarakan pendapat, dan mencapai tujuan belajar serta kegiatan bertanya dan menjawab yang dilakukan oleh siswa mampu menumbuhkan pengetahuan baru pada diri siswa (Sihombing, 2020).

Langkah-langkah dalam penerapan model pembelajaran Giving Question and Getting Answers yakni: a) guru membuat potongan-potongan kertas sebanyak dua kali dari jumlah siswa, b) guru mengintruksikan setiap siswa guna melengkapi pernyataan sebagai berikut; pada kertas 1: saya masih belum paham tentang ..., dan pada kertas 2 : saya mampu menjelaskan tentang ..., c) guru membagi siswa ke dalam kelompok kecil yang terdiri dari 4-5 orang, d) pada tiap-tiap kelompok tersebut memilih sebuah pertanyaan yang terdapat pada kartu 1 serta membuat sebuah topik yang mampu siswa jelaskan pada kertas 2, e) guru mengintruksikan untuk setiap kelompok membacakan setiap pertanyaan yang sudah siswa seleksi. Apabila dari siswa ada yang bisa menjawabnya, diberi kesempatan untuk menjawab sebuah pertanyaan tersebut. Apabila dari siswa tidak ada yang mampu menjawab, jadi guru diharuskan bisa menjawab pertanyaan tersebut, f) guru mengintruksikan untuk setiap kelompok menyampaikan ke teman-temanya di kelas apa yang mampu siswa jelaskan pada kertas 2 serta g) lalu guru mengakhiri proses pembelajaran melalui menyampaikan rangkuman serta klarifikasi dalam semua jawaban serta penjelasan dari siswa (Zaini et al., 2019). Adapun keunggulan pada model pembelajaran Giving Question and Getting Answers yakni mampu menjadikan situasi kelas sangat aktif, mampu melatih siswa untuk berani tampil dalam bertanya serta mengemukakan gagasannya secara lisan, melatih siswa untuk bertukar pengetahuan dengan temannya, membangun pengetahuannya sendiri, melatih sikap kerjasama dengan teman, serta melatih siswa untuk mengurangi kebiasaan menghafal (Kurino, 2018). Jadi, siswa mampu mengutarakan kesulitan yang ditemukan serta dialami pada saat dalam mencerna materi dari pelajaran yang diberikan. Adanya model pembelajaran Giving Question and Getting Answers ini diharapkan ada dampak positif yang dihasilkan dari siswa diantaranya adalah adanya motivasi yang tinggi dalam belajar pembelajaran PPKn sehingga prestasi belajar PPKn siswa dapat meningkat.

Model pembelajaran ini dipadukan dengan media powerpoint bertujuan untuk meningkatkan kompetensi pengetahuan PPKn dan aktivitas sisawa dalam belajar. Hal ini sependapat dengan hasil penelitian (Putra et al., 2017) media powerpoint akan membantu sebuah gagasan dan penyajian materi akan menjadi lebih menarik, dan mudah dipahami serta memiliki tujuan yang jelas pada saat dipresentasikan. Sependapat juga dengan 
(Astawa \& Tegeh, 2019) powerpoint merupakan program aplikasi yang didesain secara khusus guna dapat menayangkan program dari multimedia melalui cara yang menarik serta mengagumkan, tidak memerlukan waktu yang lama dipembuatan, gampang saat penggunaan, serta relatif murah. Media powerpoint akan memberikan konstribusi yang sangat besar dalam belajar di dalam kelas, terlebih dalam pembelajaran PPKn. Sehingga, disesuaikan dari karakteristik siswa yang sedang berada di tahap operasional konkret (Elpira \& Ghufron, 2015). Demikian, melalui bantuan media powerpoint siswa mampu melihat secara langsung materi pelajaran pada gambar slide powerpoint yang yang disajikan guru dan siswa dengan mudah memahami materi yang dijelaskan guru (Paramida \& Permadi, 2019). Dalam hal ini, pembelajaran dengan powerpoint akan mampu meningkatkan kompetensi pengetahuan serta minat siswa dalam belajar, melalui penyajian gambar-gambar dengan warna-warna yang menarik (Puspita et al., 2019).

Pernyataan ini didukung oleh empat peneliti, yakni penelitian pertama menurut (Prabawati \& Sumarti, 2018) yang menunjukkan bahwa terdapat pengaruh yang signifikan model pembelajaran Giving Question and Getting Answers terhadap hasil belajar matematika. Penelitian kedua menurut (Wardanati \& Suyato, 2018) yang menunjukkan bahwa terdapat pengaruh yang signifikan model pembelajaran Giving Question and Getting Answers terhadap prestasi belajar peserta didik yang dibuktikan dengan hasil uji independent sample t-test menunjukan bahwa nilai t empirik pada posttest sebesar 7,315 dan nilai $t$ teoritik sebesar 2,011 dengan df 48 pada taraf signifikansi 5\%. Pada penelitian ketiga menurut (Astiti et al., 2017) pembelajaran berbantuan media powerpoint dalam proses pembelajaran mempermudah siswa untuk mencerna materi yang dipelajari maka berpengaruh terhadap hasil belajar PKn siswa. Pada penelitian keempat menurut (Indradewi et al., 2017) yang menunjukkan bahwa terdapat pengaruh yang signifikan model pembelajaran kooperatif tipe Numbered Head Together berbantuan media powerpoint terhadap kompetensi pengetahuan Matematika siswa kelas V SD. Berdasarkan uraian tersebut, dapat ditarik kesimpulan model pembelajaran Giving Question and Getting Answers berbantuan media powerpoint berpengaruh terhadap kompetensi pengetahuan PPKn.

Berdasarkan pemaparan tersebut, maka dari itu dilakukan penelitian eksperimen yang berjudul pengaruh model pembelajaran Giving Question and Getting Answers berbantuan media Powerpoint terhadap kompetensi pengetahuan PPKn siswa kelas IV SD Gugus III Mengwi tahun ajaran 2019/2020. Rumusan tujuan penelitian ini adalah untuk membuktikan secara empirik ada tidaknya pengaruh yang signifikan model pembelajaran Giving Question and Getting Answers berbantuan media Powerpoint terhadap kompetensi pengetahuan PPKn siswa kelas IV SD Gugus III Mengwi tahun ajaran 2019/2020.

\section{METODE PENELITIAN}

Pada penelitian ini menggunakan desain eksperimen semu (quasi eksperimental design). Dalam melaksanakan penelitian menggunakan bentuk desain Nonequivalent Control Group Design. Pada desain ini, baik dari kelompok eksperimen serta kelompok kontrol dibandingkan serta desain ini tidak bisa sepenuhnya mengontrol variabel dari luar yang mempengaruhi pelaksanaan eksperimen. Berikut ini rancangan desain dalam penelitian yakni:

\begin{tabular}{|lrr|}
\hline $\mathrm{O}_{1}$ & $\mathrm{X}$ & $\mathrm{O}_{2}$ \\
\hline $\mathrm{O}_{3}$ & & $\mathrm{O}_{4}$ \\
\hline
\end{tabular}

Gambar 1. Rancangan Non-Equivalent Control Group Design 
Rancangan penelitian ini mengikutsertakan kedua sampel yang diberi pre-test serta post-test. Dengan memberikan pre-test ini dipakai guna mengukur equivalensi ataupun penyetaraan pada kelompok (Dantes, 2017). Melalui diberikannya pre-test di kedua sampel sebagai penyetaraan kelompok. Maka dari itu, teknik yang dipakai sebagai peyetaraan kelompok menggunakan uji-t kesetaraan pada skor pretest dengan uji syarat normalitas dan homogenitas. Kelompok yang telah setara maka dilanjutkan melalui pengundian guna menetapkan kelompok eksperimen serta kelompok kontrol. Selanjutnya, untuk kelompok eksperimen diberi perlakuan khusus, yakni dibelajarkan memakai model Giving Question and Getting Answers berbantuan media powerpoint, sebaliknya kelompok kontrol dibelajarkan secara konvensional. Kemudian, pada akhir penelitian dari dua sampel diberikan post-test guna mendapati kompetensi pengetahuan PPKn. Dilanjutkan pada nilai pretest serta nilai post-test kemudian dinormalisasikan melalui memakai rumus Gain Skor..

Populasi ialah daerah generalisasi yang terdiri dari objek ataupun subjek, yang mempunyai tingkat maupun karakter jelas sehingga ditetapkan dari peneliti guna dipelajari serta akhirnya ditarik kesimpulan (Sugiyono, 2017). Populasi pada suatu penelitian ialah seluruh kelas IV SD Gugus III Mengwi Tahun Ajaran 2019/2020, terdiri sebanyak 9 kelas berdasarkan 7 sekolah. Jadi, jumlah untuk siswa pada populasi penelitian yaitu 232 siswa, yang sudah tersebar di sembilan kelas. Teknik pengambilan sampel dalam penelitian ini menggunkan teknik random sampling. Pemilihan sampel tidak mengadakan pengacakan perseorangan melainkan hanya pengacakan pada kelas. Sesudah diketahui, jika keseluruhan kelas IV di SD Gugus III Mengwi tidak ada kelas yang unggulan ataupun semua kelas dinyatakan setara, lalu pengundian sudah bisa dilaksanakan. Cara pengundiannya dilaksanakan melalui menuliskan seluruh nama kelas IV yang ada di seluruh SD Negeri Gugus III Mengwi pada selembar kertas, lalu digulung. Selanjutnya, kertas yang sudah digulung tersebut dimasukkan dalam kotak selanjutnya diundi. Melakukan pengundian melalui mengeluarkan dua gulungan kertas dari kotak dengan cara bergantian. Pada dua gulungan kertas yang didapat ialah sampel penelitian. Dua sampel tersebut diberi pretest serta diuji untuk kesetaraannya. Sesudah diketahui setara selanjutnya dilakukan pengundian kembali untuk menentukan kelas eksperimen dan kelas kontrol. Berdasarkan undian, kelas yang keluar pertama kali dipilih sebagai kelas eksperimen serta kelas yang keluar kedua ialah kelas kontrol. Pada undian yang dilakukan, kelas IV SD No. 4 Sading jumlahnya 36 siswa muncul pada undian pertama dan dijadikan sebagai kelas eksperimen, sedangkan kelas IV SD No. 2 Sading jumlahnya 32 siswa muncul pada undian kedua dan dijadikan sebagai kelas kontrol. Tahap selanjutnya dapat diberikan pretest. Hasil skor pretest dianalisis dengan diuji prasyarat yang dilakukan yaitu uji normalitas dengan teknik Kolmogorov-Smirnov dan uji homogenitas varians. Hasil nilai atau skor pretest dianalisis dengan uji t kesetaraan. Apabila kelompok sampel sudah setara maka dilanjutkan dengan memberikan perlakuan. Kelas eksperimen diberi perlakuan yakni model pembelajaran Giving Question and Getting Answers berbantuan media powerpoint serta kelas kontrol yang dibelajarkan menggunakan pembelajaran konvensional. Pengumpulan data dilaksanakan pada siswa kelas IV SD No. 4 Sading dan kelas IV SD No. 2 Sading yang menjadi sampel penelitian. Data yang diperlukan adalah hasil skor kompetensi pengetahuan PPKn dengan metode tes tertulis.

Sesuai dengan data yang dikumpulkan pada penelitian yakni data dari kompetensi pengetahuan PPKn siswa kelas IV SD Gugus III Mengwi Tahun Ajaran 2019/2020. Instrument yang digunakan adalah tes tertulis dengan pilihan ganda biasa, setiap di butir soal terdiri dari empat jawaban alternatif yakni a, b, c, serta d yang terdapat satu jawaban benar. Untuk tes kompetensi pengetahuan PPKn yang dipakai penelitian yang berjumlah 50 butir soal yang sudah di uji validitas, uji tingkat kesukaran butir tes, uji daya beda serta uji reliabilitas.Tes terlebih dahulu di uji cobakan ke kelas V yang berjumlah 50 butir soal untuk mengetahui bahwa soal tersebut susah atau mudah, dengan menggunakan uji gain 
skor maka soal pretest dan soal posttest yang digunakan sama. Instrumen ini digunakan untuk mengukur kompetensi pengetahuan PPKn siswa pada dua kelas sampel. Instrument soal ini di uji validitas butirnya menggunakan rumus product moment. Dari data pretest yang sudah dikumpulkan maka perlu dianalisis, dengan teknik analisis statistik inferensial yakni uji-t melalui rumus polled varian. Pada statistik inferensial data yang dianalisis adalah data gains skor yang ternormalisasi dari hasil pretest dan posttest.

Berdasarkan teknik yang dipakai dalam menganalisis data posttest dihitung dengan analisis parametis uji-t formula gain skor berdasarkan data berdistribusi normal dan homogen. Selanjutnya, sebelum dianalisis memakai uji-t kedua sampel diujikan prasyarat analisis yaitu uji normalitas sebaran data memakai uji Kolmogorov-Smirnov serta uji homogenitas varians memakai uji Fisher. Pada uji normalitas sebaran data memakai uji Kolmogorov-Smirnov melalui kriteria pengujian dengan taraf signifikansi 5\% kalau nilai maksimum $\left|\mathrm{F}_{\mathrm{T}}-\mathrm{F}_{\mathrm{S}}\right| \leq$ nilai tabel Kolmogorov-Smirnov, bahwa data berdistribusi normal. Kalau nilai maksimum $\left|\mathrm{F}_{\mathrm{T}}-\mathrm{F}_{\mathrm{S}}\right|>$ nilai tabel Kolmogorov-Smirnov, bahwa data tidak berdistribusi normal. Pada uji homogenitas varians menggunakan uji $\mathrm{F}$ (Fisher) melalui kriteria pengujian taraf signifikansi $5 \%$ serta derajat kebebasan dalam pembilang $n_{1}-1$ kemudian derajat kebebasan dalam penyebut $n_{2}-1$, kalau harga $F_{\text {hitung }} \leq F_{\text {tabel }}$ bahwa sampel artinya homogen sedangkan kalau harga $F_{\text {hitung }}>F_{\text {tabel }}$ bahwa sampel artinya tidak homogen. Hipotesis statistik yang diuji yakni $\mathrm{H}_{0}$ yaitu tidak terdapat perbedaan yang signifikan kompetensi pengetahuan PPKn kelompok siswa yang dibelajarkan menggunakan model pembelajaran Giving Question and Getting Answers berbantuan media powerpoint serta kelompok siswa yang dibelajarkan menggunakan pembelajaran konvensional pada kelas IV SD Gugus III Mengwi Tahun Ajaran 2019/2020. Kriteria pengujian melalui taraf signifikan 5\% lalu dk $=\mathrm{n}_{1}+\mathrm{n}_{2}-2$ serta kriteria jika harga $\mathrm{t}_{\text {hitung }} \leq \mathrm{t}_{\text {tabel }}$, bahwa $\mathrm{H}_{0}$ diterima serta $\mathrm{H}_{\mathrm{a}}$ ditolak, serta jika harga $t_{\text {hitung }}>\mathrm{t}_{\text {tabel }}$ bahwa $\mathrm{H}_{0}$ ditolak serta $\mathrm{H}_{\mathrm{a}}$ diterima.

\section{HASIL DAN PEMBAHASAN}

\section{HASIL}

Pada hasil dari penelitian menjabarkan mengenai nilai rata-rata (mean), standar deviasi, dan varians dari kompetensi pengetahuan PPKn siswa kelas IV SD No. 4 Sading selaku kelompok eksperimen yang dibelajarkan memakai model pembelajaran Giving Question and Getting Answers berbantuan media powerpoint, dan siswa kelas IV SD No. 2 Sading yang dibelajarakan menggunakan pembelajaran konvensional. Post-test diberikan setelah 6 kali perlakuan di kedua sampel. Kemudian, data yang dianalisis pada penelitian ialah data hasil pre-test serta post-test kompetensi pengetahuan PPKn di kedua sampel. Data pre-test dipakai guna mengukur kesetaraan kelompok kelas. Sedangakan, post-test diberi guna mengetahui perbedaan kompetensi pengetahuan PPKn siswa pada kedua sampel. Jumlahnya siswa yang ada di kelompok eksperimen ialah 36 siswa, serta kelompok kontrol berjumlah 32 siswa. Dengan demikian, jumlah keseluruhan sampel penelitian ialah 68 siswa. Berikut hasil rekapitulasi data bisa dicermati pada tabel 1 yakni:

Tabel 1. Rekapitulasi Data Hasil Kompetensi Pengetahuan PPKn Kelompok Kelas Eksperimen dan Kelompok Kontrol

\begin{tabular}{ccc}
\hline Data & Kelompok Eksperimen & Kelompok Kontrol \\
\hline Mean & 0,655 & 0,538 \\
Standar Deviasi & 0,239 & 0,232 \\
Varians & 0,057 & 0,054
\end{tabular}


Berdasarkan hasil penelitian tersebut, maka nilai mean melalui gain skor ternormalisasi kelompok eksperimen yakni $\bar{X}=0,655$ beserta standar deviasi 0,239 dan varians 0,057 , sedangkan nilai mean pada gain skor ternormalisasi di kelompok kontrol yakni $\bar{X}=0,538$ beserta standar deviasi 0,232 serta varians 0,054 . Dari hasil data perhitungan yang didapat, menerangkan bahwa gain skor kompetensi pengetahuan PPKn kelompok eksperimen yang mengikuti pembelajaran Giving Question and Getting Answers berbantuan media powerpoint mendapat nilai rata-rata yang lebih tinggi daripada kelompok kontrol yang mengikuti lewat pembelajaran konvensional.

Sesuai dari hasil uji normalitas sebaran data memakai uji Kolmogorov Smirnov data nilai gain skor kompetensi pengetahuan PPKn pada kelompok eksperimen didapati nilai maksimum $|\mathrm{Ft}-\mathrm{Fs}|=0,131$ melalui nilai tabel Kolmogrov Smirnov melalui taraf signifikansi $5 \%=0,221$ yaitu $0,131 \leq 0,221$. Berdasarkan hasil tersebut, maka menunjukkan data di kelompok eksperimen bahwa berdistribusi normal. Sedangkan, data nilai gain skor kompetensi pengetahuan PPKn di kelompok kontrol didapati nilai maksimum $|\mathrm{Ft}-\mathrm{Fs}|=$ 0,101 melalui nilai tabel Kolmogrov Smirnov melalui taraf signifikansi 5\% =0,234 yaitu $0,101 \leq 0,234$. Berdasarkan hasil tersebut, maka berdistribusi normal yang menunjukkan data kelompok kontrol.

Kedua sampel yang dinyatakan berdistribusi normal, selanjutnya dilaksanakan uji homogenitas varians sehingga didapat hasil nilai dari $F_{\text {hitung }}=1,056$ dengan nilai $F_{\text {tabel }}$ melalui taraf signifikansi $5 \%$ kemudian $\mathrm{dk}$ pembilang $=35$ serta $\mathrm{dk}$ penyebut $=31$ ialah 1,840, jadi didapat perbandingan $F_{\text {hitung }} \leq \mathrm{F}_{\text {tabel }}$ yakni 1,056 $\leq 1,840$. Berdasarkan demikian, dapat dinyatakan data dua sampel mempunyai varians yang homogen. Berlandaskan dari hasil uji prasyarat, didapat kedua sampel berdistribusi normal serta homogen kemudian bisa dilanjutkan lewat menguji hipotesis menggunakan statistika parametrik memakai ujit melalui rumus polled varians. Hipotesis penelitian yang diujikan pada penelitian ini ialah hipotesis nol $\left(\mathrm{H}_{0}\right)$ yakni tidak terdapat perbedaan yang signifikan kompetensi pengetahuan PPKn kelompok siswa yang dibelajarkan menggunakan model pembelajaran Giving Question and Getting Answers berbantuan media powerpoint dan kelompok siswa yang dibelajarkan menggunakan pembelajaran konvensional kelas IV SD Gugus III Mengwi Tahun Ajaran 2019/2020. Berikut ini dijabarkan rekapitulasi hasil dari analisis data melalui uji-t dalam tabel 2 yakni:

Tabel 2. Rekapitulasi Uji-t Kelompok Sampel Penelitian

\begin{tabular}{llcccccc}
\hline No. & Kelompok Sampel & $\mathrm{N}$ & $\mathrm{Dk}$ & $\bar{X}$ & $\mathrm{t}_{\text {hitung }}$ & $\mathrm{t}_{\text {tabel }}$ & Keterangan \\
\hline 1. & Eksperimen & 36 & & 0.655 & & & \\
2. & Kontrol & 32 & 66 & 0.538 & 2,053 & 1,997 & $\mathrm{H}_{0}$ ditolak \\
\hline
\end{tabular}

\section{PEMBAHASAN}

Penerapan model pembelajaran Giving Question and Getting Answers berbantuan media powerpoint berpengaruh terhadap kompetensi pengetahuan PPKn siswa kelas IV SD Gugus III Mengwi Tahun Ajaran 2019/2020. Hal tersebut dikarenakan model pembelajaran Giving Question and Getting Answers berbantuan media powerpoint mampu membangkitkan siswa untuk menjadi lebih aktif selagi berlangsungnya pembelajaran di kelas. Aktifnya proses belajar mengajar ini dikarenakan memakai model Giving Question and Getting Answers melalui berbantuan media powerpoint yang memberikan siswa sebuah permasalahan dengan berbagai solusi penyelesaian agar siswa mampu untuk 
menyelesaikan permasalahan sesuai kemampuan yang dimilikinya dan mengembangkan kemampuan siswa dari pada sekedar mengetahuinya. Sehingga siswa dapat mengkontruksi pengetahuannya sendiri dengan menuliskan permasalahan yang didapat dalam sebuah kertas tanya jawab. Pada model pembelajaran tersebut dipadukan melalui media powerpoint yang bisa menjadikan siswa lebih mencerna materi serta diimbangi dengan siswa berpikir kritis dan materi diterangkan lebih konkret. Sehingga, menjadikan suatu pembelajaran sangat bermakna serta tidak membosankan. Ini dikarenakan model Giving Question and Getting Answers yang berbantuan melalui media powerpoint menekankan guna siswa lebih aktif dalam berpikir sehingga siswa mampu membangun pengetahuannya sendiri dan memberikan pemecahan masalah kepada siswa-siswa yang lainnya. Lain daripada itu, saat melangsungkan pembelajaran siswa sangat bersemangat serta lebih antusias dalam mengemukakan gagasan awal dikarenakan guru menstimulus pengetahuan yang dimiliki siswa melalui bantuan powerpoint yang masih bersangkutan sama materi pelajaran. Dalam proses berlangsunya pembelajaran, guru menerapkan lima tahapan dalam model Giving Question and Getting Answers dengan berbantuan dari media powerpoint, yakni: (a) persiapan, (b) menyajikan informasi, (c) pemberian masalah, (d) penyampaian hasil, (e) menutup kegiatan pembelajaran.

Pada pembelajaran melalui memakai model Giving Question and Getting Answers dengan berbantuan dari media powerpoint mempunyai suatu keunggulan diantaranya: (a) siswa menjadi lebih aktif serta mampu mengkonstruksi gagasan yang dipunya melalui berani bertanya dan mengemukakan pendapat secara lisan, (b) siswa bisa terlibat langsung saat menemukan suatu konsep kemudian pembelajaran jadi sangat berarti, (c) siswa terbiasa belajar mandiri untuk memecahkan masalah, serta (d) supaya pada saat penyampaian suatu materi dari guru lebih mudah dimengerti siswa karena ditayangkan dengan media pembelajaran powerpoint sehingga proses belajar lebih efektif.

Sangat berbeda dari berlangsunya pembelajaran yang berada di kelompok kontrol. Pada pelaksanaan pembelajaran di kelompok kontrol kurang berlngsung dengan optimal dikarenakan sekedar menerapakan pembelajaran konvensional yang sudah biasa dipergunakan oleh guru di kelas yang dalam pelaksanaan di kelas tidak terstruktur secara sistematis. Secara demikian, membuat pembelajaran dirasakan semakin monoton kemudian siswa kurangnya aktif pada saat proses pembelajaran. Kurangnya siswa saat menguasai materi dikarena media pembelajaran yang disediakan guru berupa gambar yang ada di buku siswa. Secara tidak langsung melalui pembelajaran tersebut, membuat suatu konsep menjadi kurang mampu dimengerti siswa sehingga pembelajaran tersebut jadi kurang bermanfaat kedepannya. Dengan demikian, rata-rata gain skor dinormalisasi kompetensi pengetahuan PPKn menggunakan pernerapan model Giving Question and Getting Answers berbantuan media powerpoint lebih tinggi daripada rata-rata gain skor dinormalisasi kompetensi pengetahuan PPKn siswa yang dibelajarkan memakai pembelajaran konvensional.

Hasil penelitian ini juga mendukung penelitian yang dilakukan oleh Asmini (2020) yang menunjukan bahwa model pembelajaran Giving Question and Getting Answers yang dikembangkan dalam mata pelajaran IPS melalui kegiatan bertanya dan menjawab yang merupakan hal yang sangat esensial dalam pola interaksi antara guru dan siswa dalam proses pembelajaran yang mampu menumbuhkan pengetahuan baru pada diri siswa. Dengan diterapkannya model pembelajaran Giving Question and Getting Answers didapatkan meningkatnya prestasi belajar siswa dari awal, siklus I dan siklus II ini dikarenakan siswa sudah mampu beradaptasi dengan model pembelajaran baru sehingga siswa mampu menguasai materi pembelajaran pada mata pelajaran IPS lebih optimal.

Kemudian penelitian ini juga sejalan dengan penelitian yang dilakukan (Sundari et al., 2019) yang menunjukan bahwa model pembelajaran Giving Question and Getting Answers yang dikembangkan dalam mata pembelajaran Matematika melalui tiga asfek pengukuruan keefektifan yaitu observasi, tes dan angket dengan menggunakan model giving question and getting answer yang membuat siswa terlibat aktif dalam mengikuti 
proses pembelajaran, tumbuhnya keberanian, kerjasama tim dan rasa percaya diri siswa dalam mengeluarkan pendapat. Aktivitas belajar siswa selama pembelajaran matematika dengan menggunakan model ini dikategorikan tinggi dengan rata-rata persentase skor aktivitas 72,7. Selanjutnya ketuntasan belajar siswa secara klasikal mencapai $78,1 \%$. Kemudian, sikap siswa terhadap pembelajaran matematika dengan menggunakan model giving question and getting answer tergolong positif dengan rata-rata persentase skor 77,9. Berkaitan dengan hasil penelitian yang telah dilakukan, model model giving question and getting answer dapat dijadikan salah satu alternative untuk mengatasi masalah keaktifan siswa, sikap siswa, serta ketuntasan belajar siswa terhadap proses pembelajaran.

Hasil daripada penelitian ini memiliki persamaan penelitian yang sudah dilaksanakan sebelumnya yang relevan dan mendukung hasil penelitian relevan. Pada penelitian ini mendukung hasil penelitian yang yang dilakukan oleh (Prabawati \& Sumarti, 2018) yang menerangkan jika terdapat perbedaan yang signifikan hasil belajar matematika antara kelompok siswa yang dibelajarkan dengan penggunaan model pembelajaran Giving Question and Getting Answers serta kelompok dari siswa yang dapat dibelajarkan melalui penggunaan model pada pembelajaran konvensional siswa kelas V di SD Gugus IX Kecamatan Banjar Kabupaten Buleleng Tahun Pelajaran 2017/2018 yang dibuktikan sesuai hasil analisis dari uji-t dengan $\mathrm{t}_{\text {hitung }}=4,51>\mathrm{t}_{\text {tabel }}=2,08$.

Berdasarkan pemaparan tersebut dapat ditarik kesimpulan bahwa penelitian ini mampu memberikan temuan baru yang dapat membantu proses pembelajaran. Dikarenakan model dan media pembelajaran ini dapat menimbulkan keaktifan siswa untuk saling bertukar pendapat dengan bertanya jawab kepada teman maupun guru dan dengan mudah untuk siswa memahami materi pembelajaran yang disertai gambar dan animasi melalui media powerpoint. Sehingga implikasi dari penelitian ini nantinya dapat dijadikan sebagai salah satu referensi serta bisa diterapkan diseluruh sekolah dasar dengan menggunakan model pembelajaran Giving Question and Getting Answers berbantuan media powerpoint.

\section{SIMPULAN}

Sesuai dengan hasil pembahasan serta analisis, hasil uji-t didapat thitung yaitu 2,053, dan nilai $t_{\text {tabel }}$ melalui taraf signifikansinya $5 \%$ pada dk yaitu 66 menerangkan nilai $t_{\text {tabel }}$ yaitu 1,997. Jadi, didapat hasil dari analisis nilai $t_{\text {hitung }}$ yaitu 2,053 $>t_{\text {tabel }}$ yaitu 1,997 bahwa $\mathrm{H}_{0}$ ditolak serta $\mathrm{H}_{\mathrm{a}}$ diterima. Analisis ini menunjukkan bahwa terdapat perbedaan yang signifikan kompetensi pengetahuan PPKn antara kelompok siswa yang dibelajarkan menggunakan model pembelajaran Giving Question and Getting Answers berbantuan media powerpoint dengan kelompok siswa yang dibelajarkan menggunakan pembelajaran konvensional pada kelas IV SD Gugus III Mengwi Tahun Ajaran 2019/2020. Jadi, dapat disimpulkan bahwa model pembelajaran Giving Question and Getting Answers berbantuan media powerpoint berpengaruh terhadap kompetensi pengetahuan PPKn siswa kelas IV SD Gugus III Mengwi Tahun Ajaran 2019/2020.

\section{DAFTAR PUSTAKA}

Aprilia, L. A., Slameto, S., \& Radia, E. H. (2018). Meningkatkan Hasil Belajar PPKn Melalui Model Pembelajaran Numbered Heads Together Berbasis Kurikulum 2013. WACANA AKADEMIKA: Majalah Ilmiah Kependidikan, 2(1), 85-98. https://doi.org/10.30738/wa.v2i1.2530

Asmini, I. A. K. R. (2020). Penggunaan Model Pembelajaran Giving Questions and Getting Answer (GQGA) Sebagai Upaya Meningkatkan Prestasi Belajar IPS. Journal of Education Action Research, 4(2), 219-225. https://doi.org/10.23887/jear.v4i2.25004 
Astawa, P. A., \& Tegeh, I. M. (2019). Pengaruh Model Pembelajaran Kooperatif Tipe Make A Match Berbantuan Media Powerpoint Terhadap Hasil Belajar IPA. Jurnal Ilmiah Sekolah Dasar, 3(1), 98-106. https://doi.org/10.23887/jisd.v3i1.17663

Astiti, N. K. A., Suarjana, I. M., \& Arini, N. W. (2017). Pengaruh Model Pembelajaran VCT Berbantuan Power Point Terhadap Hasil Belajar PKn Kelas V. E-Journal PGSD Universitas Pendidikan Ganesha, 5(2), 1-10.

Ayuningsih, N. P., \& Ciptahadi, K. G. O. (2020). Pengaruh Model Pembelajaran Giving Question And Getting Answer Terhadap Kecerdasan Logis Matematis. Jurnal Pendidikan Matematika, 11(1), 134-142.

Dantes, N. (2017). Desain Eksperimen dan Analisis Data. Depok: PT Raja Grafindo Persada.

Elpira, N., \& Ghufron, A. (2015). Pengaruh Penggunaan Media Powerpoint Terhadap Minat Dan Hasil Belajar IPA Siswa Kelas IV SD. Jurnal Inovasi Teknologi Pendidikan, 2(1), 94-104. http://journal.uny.ac.id/index.php/jitp\%0APENGEMBANGAN

Fitriani, W., Sanapiah, S., \& Pujilestari, P. (2016). Penggunaan Metode Giving Question and Getting Answer Untuk Meningkatkan Hasil Belajar Siswa Pada Materi Lingkaran. Media Pendidikan Matematika, 6(1), 18-29. https://doi.org/10.33394/mpm.v6i1.1688

Harahap, S. E. (2018). Meningkatkan Hasil Belajar PPKn Melalui Model Pembelajaran TGT (Team Game Tournament) Siswa Kelas 5 SD Negeri 164525 Tebing Tinggi. Elementary School Journal, 8(2), 101-109. https://doi.org/https://doi.org/10.24114/esjpgsd.v8i2.10378

Ifnasari, I. D. A. (2018). Penerapan Model Problem Based Learning (PBL) untuk Meningkatkan Proses dan Hasil Belajar Muatan PPKn pada Tema 8 Subtema 1. Jurnal Penelitian Dan Pengembangan Pendidikan, 2(2), 182-189. https://doi.org/10.23887/jppp.v2i2.15465

Indradewi, N. N. A., Putra, I. K. A., \& Abadi, I. B. G. S. (2017). Pengaruh Model Pembelajaran Kooperatif Tipe Numbered Head Together Berbantuan Media Powerpoint Terhadap Kompetensi Pengetahuan Matematika. E-Journal PGSD Universitas Pendidikan Ganesha, 5(2), 1-10.

Kurino, Y. D. (2018). Model Giving Question and Getting Answer Untuk Meningkatkan Hasil Belajar Siswa Sekolah Dasar. Jurnal Dicactical Mathematics, 1(1), 34-39.

Nengsi, S., \& Oktaria, R. (2019). Pengaruh Model Pembelajaran GQGA (Giving Question and Getting Answer) terhadap Hasil Belajar Siswa. BIOEDUSAINS: Jurnal Pendidikan Biologi Dan Sains, 2(2), 111-121. https://doi.org/10.31539/bioedusains.v2i2.959

Nurhafni, \& Khasanah. (2019). Model Pendidikan Kesetaraan Paket A Setara SD /MI Mata Pelajaran PPKn. Akademika Jurnal Tenologi Pendidikan, 8(2), 169-183. https://doi.org/10.34005/akademika.v8i02.500

Paramida, S., \& Permadi, A. S. (2019). Penerapan Model Pembelajaran Circuit Learning Berbantuan Media Microsoft Powerpoint Untuk Meningkatkan Hasil Belajar IPS Pada Peserta Didik Kelas IV SDN 3 Palangka Tahun Pelajaran 2016/2017. BITNET Jurnal Pendidikan Teknologi Informasi, 4(1), 25-29. https://doi.org/10.1017/CBO9781107415324.004 
Prabawati, I. G. A. K., \& Sumarti, M. (2018). Pengaruh Strategi Pembelajaran Giving Question and Getting Answer ( GQGA ) terhadap Hasil Belajar Matematika. MIMBAR PGSD Undiksha, 6(2), 112-119.

Puspita, N. P. M., Asri, I. G. A. A., \& Ardana, I. K. (2019). Pengaruh Model Pembelajaran Kooperatif Tipe Jigsaw Berbantuan Media Powerpoint Terhadap Kompetensi Pengetahuan PPKn. Media Komunikasi FPIPS, 17(1), 1-10. https://doi.org/10.23887/mkfis.v17i2.22221

Putra, I. K. S., Sudana, D. N., \& Tastra, I. D. K. (2017). Pengaruh Model Pembelajaran Kooperatif Tipe Snowball Throwing Berbantuan Lagu Daerah Terhadap Hasil Belajar IPA. E-Journal PGSD Universitas Pendidikan Ganesha, 5(1-12). https://doi.org/10.23887/jippg.v2i1.18085

Riza, N., \& Sthephani, A. (2020). Giving Question and Getting Answer ( GQGA ): suatu Eksperimen Terhadap Motivasi Belajar Matematika Siswa. AKSIOMATIK, 8(1), 7380.

Sastra, E., Yogica, R., \& Syamsurizal, R. D. (2020). Pengaruh Model Pembelajaran Aktif Tipe Giving Question And Getting Answers Bermuatan Literasi Sains Terhadap Kompetensi Belajar Peserta Didik Pada Materi Virus Di SMA Adabiah Padang. BIOILMI, 6(1), 28-38.

Selly Lindayani, N. P., Putra, M., \& Manuaba, I. B. S. (2019). Pengaruh Model Pembelajaran Value Clrification Technique Bermuatan Nilai Karakter Terhadap Kompetensi Pengetahuan PPKn. Thinking Skills and Creativity Journal, 2(2), 47-56. https://doi.org/10.23887/tscj.v2i2.20709

Setiadi, H. (2016). Pelaksanaan Penilaian Pada Kurikulum 2013. Jurnal Penelitian Dan Evaluasi Pendidikan, 20(2), 166-178. https://doi.org/10.21831/pep.v20i2.7173

Sihombing, R. (2020). Penerapan Model Pembelajaran Kooperatif Giving Question And Getting Answer Terhadap Aktivitas Belajar Dan Hasil Belajar Siswa Pada Materi Menerapkan Prosedur Kegiatan Rapat. Jurnal Teknologi Pendidikan (JTP), 13(1), 57-67. https://doi.org/10.24114/jtp.v13i1.18000

Sudirman. (2015). Pengaruh Model Belajar Aktif Tipe Giving Question And Getting Answers (GQGA) Terhadap Prestasi Belajar Matematika Siswa. 7(1), 1-6.

Sugiyono. (2017). Metode Penelitian Kuantitatif dan R \& D. Bandung: Alfabeta.

Sujana, I. W. C. (2019). Fungsi Dan Tujuan Pendidikan Indonesia. Adi Widya: Jurnal Pendidikan Dasar, 4(1), 29-39. https://doi.org/10.25078/aw.v4i1.927

Sundari, A., Lusiana, \& Marhamah. (2019). Penerapan Model Pembelajaran Giving Question And Getting Answer Pada Pembelajaran Matematika Siswa SMPN 48 Palembang. Jurnal Inovasi Pendidikan Matematika, 1(2), 154-162. https://doi.org/10.1017/CBO9781107415324.004

Tukiran. (2019). Hubungan Pembelajaran PPKn Dengan Pengalaman Nilai-Nilai Sila I Pancasila. 7(2), 121-128.

Wardanati, I., \& Suyato. (2018). Pengaruh Penggunaan Metode Pembelajaran Giving Question And Getting Answer Dalam Pembelajaran PKn Terhadap Keaktifan Dan Prestasi Belajar Peserta Didik Kelas VIII SMP Muhammadiyah Mungkid. Jurnal Pendidikan Kewarganegaraan Dan Hukum, 7(5), 478-488.

Zaini, H., Munthe, B., \& Aryani, S. A. (2019). Strategi Pembelajaran Aktif. Yogyakarta: 
Widiantari, Asri, Negara (2020)

Jurnal EDUTECH Universitas Pendidikan Ganesha. Vol. 8 No. (2) pp. 107-119

https://ejournal.undiksha.ac.id/index.php/JEU

CTSD. 